\title{
Research on Integration and Socialization of Procuratorial Work of the Juveniles
}

\author{
Yanli $\mathrm{Yu}$ \\ China University of Political Science and Law \\ Beijing, China 100089
}

\begin{abstract}
With the judicial concept of juvenile deeply rooted in the hearts of the people, the procuratorial work of juveniles has made remarkable progress in recent years. However, the related system guarantee and social support are still lagging behind, which restrict the progress of the procuratorial work of the juvenile to some extent. From the perspective of integration and socialization, this paper explores the development path of procuratorial work of the juveniles.
\end{abstract}

Keywords-procuratorial work of the juveniles; integration; socialization

\section{INTRODUCTION}

In recent years, the procuratorial work of the juveniles has experienced vigorous development. From the supreme people's procuratorate to the local people's procuratorates at all levels, independent juvenile procuratorates or special case handling groups and personnel have been established one after another, and the ranks of juvenile procurators have been growing constantly. The Supreme Judicial Court and the Supreme People's Procuratorate issue the typical case of the juveniles and work guideline every year. The judicial concept of juvenile is not only deeply rooted in the hearts of the academia and juvenile prosecutors handling a case, but also recognized by the society. However, there are still many problems that should be further explored in the procuratorial work of the juveniles, such as the lack of social support system, the difficulty of finding suitable nursing bases for juveniles who do not be prosecuted under the conditional conditions, the lack of social work and psychological counseling resources in many places, and the social investigation and psychological counseling conducted by the prosecutors. The functions of procuratorial work of the juveniles change from the integration of arrest and prosecution to the integration of arrest, prosecution, supervision and prevention, and then to the exploration of public prosecution, and are becoming more and more. However, there are still some problems, such as how to ensure the refinement and specialization, and what the functional boundaries are, etc. The procuratorial work of the juveniles is not only a "technical work" to accurately grasp the case and apply the law, but also an "artistic work" to resolve social risks, adjust family contradictions and guard the future of the country. The procuratorial work of the juveniles is based on the law, but can't stop at the law, should be based on the procuratorial organs, but also can't stop at the level of procuratorial organs. This article discusses how to improve the procuratorial work of the juveniles from the aspects of integration and socialization.

\section{INTEGRATION OF THE PROCURATORIAL WORK OF THE JUVENILES}

\section{A. Integration of the Procuratorial Work of the Juveniles with Other Departments Within Procuratorial Organs}

From the perspective of the internal organs and functions of procuratorial organs, the integration of the functions of arrest, prosecution and supervision and prevention of juvenile prosecution should break the barriers of the internal organs of procuratorial organs. At the same time, it is necessary to effectively integrate the protection functions of juvenile prosecution scattered in various business departments of procuratorial organs, establish an independent procuratorial organ for juveniles, and realize the intensification and specialization of judicial protection of the juveniles. The same prosecutor or case-handling team follow up the same case, which can comprehensively grasp the situation of juvenile cases and the physical and mental condition of juveniles, carry out targeted assistance, education, care and assistance, and effectively improve the quality and effect of work. However, the case handling has put forward higher requirements for the internal supervision and restriction. It is necessary to strictly manage the process and quality of case handling, and strictly observe the discipline of handling cases. It should ensure that undertakers handle juvenile cases in accordance with the law and fairness. Most of the juvenile procuratorial cadres are enriched by the personnel of the investigation and supervision department and the public prosecution department. Therefore, the newly established juvenile procuratorial department can carry out internal cross-training, and the former professional experts of investigation and supervision and the backbone of public prosecution can respectively teach relevant professional knowledge and experience in handling cases. At present, the exploration of civil and administrative procuratorial supervision into juvenile procuratorial work needs to fully demonstrate and study the boundaries of duties and the way of performing their duties. Juvenile procurators who have not been engaged in civil and administrative procuratorial work should be trained in relevant business in a timely manner so as to smoothly link up their work. 


\section{B. Integration of Procuratorial Work of the Juveniles with Public Security and Courts}

Investigation, prosecution, trial, correction, legal aid and other social protection agencies have not yet formed a network. In the field of juvenile criminal justice protection, the "one-stop process of politics and law" has its own shortcomings, which affects the effect of juvenile justice socialization. In some areas, the development of three juvenile procuratorial organs in the public security organs, procuratorial organs and people's courts is inconsistent, and the judicial concept of personnel is not uniform, which makes it difficult to form a joint force to protect juveniles. For example, in the area of juvenile criminal record preservation, the procuratorial organ has made a decision on the preservation of juvenile criminal record and sent the notice of the preservation to the public security organ. However, in some areas, the requirement of maintaining stability is higher, and the stipulation of the preservation of criminal record is not strictly enforced. Instead, it made criminal records of juvenile public according to the local demand of combating crime. The three organs of public security organs, procuratorial organs and people's courts should unify the concept of juvenile justice, strengthen the construction of business communication and information communication platform, and strictly implement the special judicial protection requirements for the juveniles.

\section{Integration of Procuratorial Work of the Juveniles with Government Administration}

In 2010, the six ministries and commissions of the Central Committee jointly signed "Several Opinions on Further Establishing and Perfecting the Complementary Work System for Handling Juvenile Criminal Cases". Although this opinion provides a reference for the communication and consultation between different departments in handling cases, there are still some inconsistencies in the law enforcement standards of different departments in the actual handling of cases. For some jobs with unclear boundaries, there is also a phenomenon of mutual prevarication and nagging. Who will take the initiative to coordinate, who will get through all aspects of the work, who will follow up to ensure the rights and interests of children? It lacks a supervisor and responsible department. Firstly, it is necessary to establish an information platform for the protection of the juveniles, so as to realize the circulation of information on the Internet, publicize law enforcement on the Internet, and supervise the publicity on the Internet. Secondly, it can form a unified leading institute for the protection of the juveniles, clarify the specific responsibilities of various departments, and form a joint effort to do a good job in monitoring, prevention, discovery report, emergency treatment, research and referral, assistance and intervention, supervision and accountability of the protection of the juveniles.

\section{Integration of Procuratorial Work of the Juveniles with the Society}

Protecting the legitimate rights and interests of the juveniles and promoting the healthy growth is the responsibility of the society as a whole. The procuratorial organs should not only strengthen their contacts with the Communist Youth League, women's federation, civil affairs, education and other departments, but also actively mobilize social forces to participate in the protection of the juveniles, so as to form the whole society caring for the juveniles. Only in this way can we better protect the juveniles and further accelerate the process of integration of China's procuratorial work of the juveniles. And then, it will form a deep-seated and comprehensive protection mechanism. At present, the social strength in helping and educating the juveniles is obviously weak, and there is no inter-agency cooperation mechanism, which greatly hinders the formation of juvenile judicial protection. Due to the "social one-stop" disjointed or weak grass-roots political organizations, such as guaranteed pending trial, residential surveillance, community services and other judicial measures that need to play a role in society become mere formality, affecting the application of nonpenalty measures for the juveniles. It is necessary to establish a government-led juvenile judicial social service mechanism, refer the needs of judicial proceedings to relevant professional social organizations or government functional departments, and improve the matching and linking mechanism of justice with the assistance of social forces.

\section{SOCIALIZATION OF THE PROCURATORIAL WORK OF THE JUVENILES}

\section{A. The Connotation of the Socialization of Procuratorial Work of the Juveniles}

In 2012, the Supreme People's Procuratorate promulgated the Decision on Further Strengthening the Criminal Procuratorial Work of the Juveniles (hereinafter referred to as the Decision) and proposed to promote the socialization of juvenile crime prevention system. Specifically, it is necessary to integrate the social forces, to promote the improvement of the social support system of juvenile justice as the basic path, and to entrust part of the work which is not easy to accommodate but can play a positive role in saving the juvenile delinquents to the social support system. After the key tone of social forces participating in juvenile procuratorial work was established in the Decision of 2012, the Supreme People's Procuratorate further formulated the Eight Measures for Strengthening Judicial Protection of Juveniles by Procuratorial Organs (hereinafter referred to as the Eight Measures for Judicial Protection) in order to put into effect the basic idea of social forces participating in juvenile procuratorial work and in light of the reality of juvenile criminal procuratorial work in China. In order to ensure the professionalism of protecting the rights and interests of juveniles involved in prosecution and crime prevention, and to promote the establishment of a long-term mechanism for social work institutions, volunteer organizations and communities to participate in the criminal prosecution of juveniles, the procuratorial organs should turn over the work of social investigation, psychological counseling and conditional non-prosecution to professional social forces by means of government purchase of services. 
It is necessary to view the subjects involved in the procuratorial work of the juveniles from the subject point of view of the social forces, lack of uniform legal provisions. In the Guiding Opinions on the Government's Purchase of Services from Social Forces issued by the General Office of the State Council in 2013, the extension of social forces is defined as: enterprises and institutions registered according to law with the competent departments of industry and commerce, social organizations registered in the civil affairs departments according to law or exempted from registration with the approval of the State Council, and social organizations exempted from registration according to law, and social forces such as enterprises and institutions registered with the competent departments of industry and commerce. The Ministry of Housing and Urban-Rural Construction issued "Opinions on Mobilizing and Organizing Social Forces to Support the Construction of Villages and Towns in Dabieshan Mountains". Social forces include state-owned enterprises, private enterprises, financial institutions, scientific research institutions, social public welfare organizations, charitable organizations, international organizations, etc. Article 3 of the Provisions of the People's Procuratorate on the Handling of Juvenile Criminal Cases stipulates that the People's Procuratorate should strengthen its contacts and cooperation with relevant government departments, the Communist Youth League, women's federations, labor union and other people's organizations, as well as schools and juveniles' protection break the law and commit crimes. Article 25 lists the social forces involved in juvenile criminal procuratorial work as: comprehensive management, Communist Youth League, Guangong Committee, Women's Federation, civil affairs, social work management, schools, communities, enterprises, etc. It can be seen that the social forces involved in related work are different in different fields. Professor Wu Zongxian defines the social forces involved in the criminal prosecution of the juveniles as "all social resources provided by non-state finance" ${ }^{1}$. Professor Song Zhijun, on the other hand, extensively dealt with the social forces involved in juvenile criminal procuratorial work, that is, he advocated that "social forces should include not only all social resources provided by non-state finance, but also government departments, institutions and people's organizations supported by state finance other than public prosecution law"'2. In the author's opinion, starting from the maximization of children's welfare, it not only needs government departments, people's organizations and public institutions outside the public security organs, procuratorial organs and people's courts to assume statutory responsibilities, but also needs legal service institutions, psychological consultation institutions and social work institutions with professional knowledge, as well as public welfare with some experience in the field of juvenile protection to participate in. More importantly, individuals and enterprises with a sense of social responsibility and willing to contribute to the protection of minors are needed.

Wu Zongxian. On the Long-term Mechanism of Social Forces Participating in Preventing Juvenile Delinquency. Journal of East China University of Political Science and Law, No. 5, 2013.

Song Zhijun. Research on Social Participation in Juvenile Criminal Justice, Law Science Magazine, No. 2, 2016.
From the content point of view, the socialization of juvenile procuratorial work is to combine the juvenile judicial work and social work undertaken by the procuratorial organs, and form a work system that provides special judicial protection and comprehensive protection for juveniles. First, special judicial protection runs through the procuratorial work of the juveniles. In the links of case investigation, prosecution and trial, the procuratorial organs introduce social forces into the work of proper adult presence, social investigation, nursing and teaching, victim assistance, etc. in accordance with the requirements of special handling procedures of the Criminal Procedure Law. In the links of implementation, the procuratorial organs advance the execution of prohibition orders and community correction according to law. It can properly introduce social participation to provide the juveniles with life improvement, growth companionship, behavior correction, psychological counseling and so on. Second, the procuratorial organs should actively participate in social governance and comprehensively protect the rights and interests of the juveniles. The Constitution clearly stipulates that the People's Procuratorate of the People's Republic of China is the national legal supervision organ. The procuratorial organs shall have the functions and responsibilities of supervising and submitting to the courts to stop, correct and sanction all illegal acts that undermine the unification and correct implementation of the laws of the state, and shall have the corresponding allocation of powers. According to the functions and powers of legal supervision, procuratorial organs can carry out socialized protection of the infringement of juveniles' rights and interests by parents, schools, enterprises and institutions, government departments and other acts according to their functions and powers, including putting forward procuratorial suggestions, suing suggestions and directly putting forward public interest litigation, etc.

\section{B. Necessity of Socialization of Procuratorial Work of the Juveniles}

1) The socialization of the causes of juvenile delinquency: To educate, reform and rescue the juveniles, it is necessary to deeply analyze the causes of their crimes and adopt targeted measures to eliminate their risk of recidivism. Judge Shang Xiuyun, a "judge mother", once put forward that "juvenile delinquency is not only related to himself, but also the result of the comprehensive effect of various negative factors" ${ }^{3}$. The growth process of juveniles is influenced by various factors, and the causes of juvenile delinquency are also various. Family, school and social unhealthy factors may be the causes of juvenile delinquency. If some juveniles have incomplete family structure or tense family members, lack family care and behavior norms for a long time, and turn to peers for value identification, they are vulnerable to the influence of social personnel, such as smoking, drinking, going to and from discotheques and

Lin Wei, Guo Hang, Zhao Aoyu. Summary of Seminar on Juvenile Criminal Justice and Social Force Participation, Issues on Juvenile Crimes and Delinquency, No. 6 (2010). 
other bad behavior. If some juveniles are blackmailed by senior classmates or people outside the school, they will become the "little brother" of the victim in order to protect their own interests and help them extort their classmates' property.

2) The socialization of education, persuasion and rescue of the juveniles: Returning juveniles involved in crimes to society requires continuing compulsory education, training of working skills, repairing family relations, correcting bad acts and keeping criminal records. In addition to judicial assistance and legal aid, rescuing juvenile victims also requires financial assistance, psychological assistance and social assistance. In order to achieve comprehensive protection of the juveniles and reduce and prevent juvenile delinquency in the process of criminal proceedings, it must start with the social factors leading to their crimes and establish a social support system including family, school and society. Families should supervise and educate the juveniles, schools should accept the juveniles to study and receive education, and social organizations should provide jobs and skills training for the juveniles.

3) The socialization of protection scope of juveniles' rights and interests: The Constitution stipulates that the juveniles have the right to have education and protection, the Law on the Protection of the Juveniles stipulates that the juveniles have the right to subsistence, development, protection and participation, and the Law on the Prevention of Juvenile Delinquency stipulates that they are not allowed to sell tobacco and alcohol to the juveniles; the juveniles under the age of 16 shall not be released from guardianship; the juveniles are not allowed to enter commercial dance halls or other prohibitive provisions. The protection of the juveniles involves all aspects of their survival and development, including families, schools, enterprises and institutions, social organizations, etc. Therefore, the protection of the juveniles is a systematic project covering the whole society. Juvenile procuratorial work is a means to achieve the protection of the juveniles. It can't be separated from the whole protection system for the juveniles. Instead, it should represent the national power, actively assume the responsibility of protecting the juveniles, coordinate and cooperate with social forces, improve the protection system for the juveniles and enhance the protection.

IV. WAYS TO REALIZE THE INTEGRATION AND SOCIALIZATION OF PROCURATORIAL WORK OF THE JUVENILES

\section{A. To Clarify the Scope of Socialization of Juvenile Procuratorial Work}

Firstly, it is necessary to make clear which jobs are suitable for the social forces to undertake. The Eight Measures of Judicial Protection clearly assign social forces to undertake social investigation, psychological counseling and conditional non-prosecution. However, the author believes that with the further development of juvenile justice, there are still some tasks that can be authorized to social organizations in practice. For example, in the construction of nursing bases, the League Committee of Haidian District of Beijing has established 17 nursing bases, and procuratorates, public security and courts have actively promoted the juvenile judicial supporting system and social support department construction, and sign the "Management Measures for the Operation of Juvenile Care and Education in Haidian District" to promote the social care system of Haidian District increasingly perfect, and to achieve resource linkage and sharing. Since 2015, more than 40 conditional non-prosecutors have been offered nursing assistance, and 23 juveniles of critical prevention group have been offered assistance and correction.

The second is to clarify the scope of juvenile procuratorial work. The development trend of juvenile protection is comprehensive protection. Independent juvenile procuratorial organs integrate the protection of juveniles scattered in various departments of procuratorial organs, forming a working pattern of integration of the functions of arrest, prosecution, supervision and defense. Recently, they have been incorporated into the work of civil and administrative procuratorial work concerning juveniles. Proceeding from the duty of legal supervision of procuratorial organs, the work concerning the protection of juveniles' rights and interests and the prevention of crimes can be included in the scope of juveniles' procuratorial duties. However, the excessive expansion of public power may damage private rights and lead to the waste of judicial resources. The real problem is that social public welfare organizations, welfare institutions and systems are not yet complete, and it is difficult to assume more child protection responsibilities as developed countries in Europe and the United States, and the demand for child protection is imminent. Therefore, the procuratorial organs are bound to undertake litigation and rights involving the protection work of juveniles on the basis of legal supervision and national guardianship responsibilities.

\section{B. To Straighten out Working Methods}

Firstly, the more professional work should be purchased by the government, handed over to judicial social institutions and psychological consultation institutions, and the effectiveness of the work should be assessed to ensure the quality of the work. "Provisions of the People's Procuratorate for handling juvenile criminal cases" points out the overall structure of socialization of juvenile procuratorial work: leadership of the Party committee, government support, social coordination and public participation. The procuratorial organs should promote the establishment of a long-term mechanism for socialized protection of the juveniles, and establish a working system that integrates the public prosecution law. Other government departments cooperate with each other, and social public welfare organizations, caring enterprises and volunteers participate fully. For example, psychological counseling institutions provide psychological counseling services for the juveniles and their families, and judicial social workers provide social 
investigation, public welfare labor and other behavior correction support for juvenile suspects.

Second, it is necessary to promote the establishment of a juvenile procuratorial fund or charitable projects to solve the problems of economic assistance, medical treatment, education and training for the juveniles in difficult situations. At present, there are more than 170 foundations related to Juvenile Welfare in China, including China Human Rights Development Foundation, China Children's Fund, China Youth Development Foundation, China Soong Ching Ling Foundation and its branches in various provinces and municipalities. However, "only the China Human Rights Development Foundation has set up a special fund project for the juveniles involved in litigation, namely the special fund for the relief of minors involved in litigation. 4 Compared with foreign countries ruled by law, China has very few fund projects (charitable projects) for juvenile criminal justice, and the scope of services is limited. In practice, the threshold of applying for state assistance is high, and the funds of other relief channels such as public financing are limited. Therefore, special fund projects for relief of underage people in distress should be developed.

\section{CONCLUSION}

Further development of juvenile justice has made it possible for juvenile delinquency to be handled in a more professional, systematic way. In addition to the conviction and punishment, issues like minor's legitimate rights and interests, re-entry into society should also be taken into account in a juvenile criminal case process, which sets a higher demand on practice. It is inevitable for procuratorial organs handling juvenile delinquency to work with other judicial organs, governments, and social forces in a way that help move toward integration and socialization. In the face of challenges, procurators responsible for a juvenile criminal case need to define the scope of work with clear-cut job responsibilities, keep from abuse of power, and delegate professional work to professional teams. On top of that, appropriate approaches to work, coupled with wellconceived coordination between works, serve as underpinners for the development of professional forces in the society.

\section{REFERENCES}

[1] Wu Zongxian. On the Long-term Mechanism of Social Forces Participating in Preventing Juvenile Delinquency. Journal of East China University of Political Science and Law, No. 5, 2013. (in Chinese)

[2] Song Zhijun. Research on Social Participation in Juvenile Criminal Justice, Law Science Magazine, No. 2, 2016. (in Chinese)

[3] Lin Wei, Guo Hang, Zhao Aoyu. Summary of Seminar on Juvenile Criminal Justice and Social Force Participation, Issues on Juvenile Crimes and Delinquency, No. 6 (2010). (in Chinese)

4 Zou Meizhu. On the Theoretical Logic and Practice Path of Social Forces Participating in the Criminal Prosecutorial Work of Juveniles", Journal of Southwest University for Nationalities (Humanities and Social Sciences Edition), 2017, No. 8.
[4] Research Group of People's Procuratorate of Panjin City, Liaoning Province. Study on Several Issues Concerning the Integration of Juvenile Procuratorial Work, China Prosecutor, No. 8 of 2017. (in Chinese)

[5] Song Kaili. Analysis of the Perfect Path of the Juvenile Procuratoria Integration Work Mode", China Prosecutor, No. 4, 2018. (in Chinese) 